\title{
A study of oral glucose tolerance test in preeclampsia
}

\author{
Veena Singh Ghalaut ${ }^{*}$, Nirmal Gulati ${ }^{* *}$, Partap Singh Ghalaut ${ }^{\dagger}$, Simmi Kharb ${ }^{*}$
}

\begin{abstract}
Abstrak
Kehamilan akan merangsang resistensi insulin yang mengakibatkan terganggunya metabolisme karbohidrat dan meningkatnya kejadian preeklampsia-eklampsia. Terdapat pula peningkatan morbiditas dan mortalitas janin. Penelitian ini dilakukan pada 25 kasus preeklampsia ringan, 25 kasus preeklampsia berat, dan 50 wanita hamil normotensif yang sesuai umur, paritas dan usia gestasinya. Pemeriksaan klinik lengkap termasuk pemeriksaan $\mathrm{Hb}$, urin lengkap, ureum darah, asam urat, kreatinin, dan toleransi glukosa oral dilakukan. Terdapat kenaikan bermakna dalam mortalitas dan morbiditas perinatal pada preeklampsia berat. Hipoglikemia lebih banyak ditemukan pada preeklampsia berat dan hiperglikemia pada preeklampsia ringan. Pemeriksaan glukosa darah penting dalam meramalkan keadaan janin pada kasus-kasus tersebut.
\end{abstract}

\begin{abstract}
Pregnancy induces a state of insulin resistance leading to disturbed carbohydrate metabolism and increased incidence of preeclampsia-eclampsia. There is increased incidence of fetal morbidity and mortality. The present study was carried out in 25 mild preeclamptic woman, 25 severe preeclamptic woman and 50 age, parity and gestation matched normotensive pregnant women. Thorough clinical examination was done and hemoglobin, urine complete examination, blood urea, serum uric acid, creatinine and oral glucose tolerance were estimated. There is significant increase in perinatal mortality and morbidity in severe preeclampsia. Hypoglycaemia was more commonly seen in severe preeclampsia and hyperglycaemia in mild preeclampsia. Hence, blood glucose estimation is important to predict the fetal outcome in such patients.
\end{abstract}

Keywords: gestational diabetes, perinatal mortality, preterm deliveries, birth asphyxia

\section{INTRODUCTION}

Preeclampsia is a common occurrence in diabetic pregnancy and a cause of perinatal mortality. During pregnancy fasting blood glucose levels fall due to increased levels of insulin. ${ }^{1,2}$ This response is due to pregnancy induced state of peripheral resistance to insulin due to increased levels of estrogen and progesterone, human placental lactogen and insulinase activity of placenta. $^{3,4}$ Inconclusive literature is available on carbohydrate metabolism in preeclampsia. Burt ${ }^{5}$ showed a consistent impairment of carbohydrate tolerance with relative hyperglycaemia and decreased sensitivity to exogenous insulin in preeclampsia and decreased sensitivity to exogenous insulin in preeclampsia which he attributed to defective hepatic storage of carbohydrate leading to hyperglycaemia. The present study has been

\footnotetext{
* Department of Biochemistry,

** Department of Medicine,

† Department of Obstetrics and Gynaecology,

Pt. B.D. Sharma PGIMS, Rohtak-124001, Haryana, India
}

carried out for a better understanding of carbohydrae metabolism in preeclampsia and relation of abnormal glucose levels with perinatal outcome.

\section{MATERIALS AND METHODS}

One hundred patients in last trimester (28-40 weeks) of pregnancy admitted/attending antenatal clinics of Pt. BDS, PGIMS, Rohtak, India were studied in two groups. Group I subdivided as group 1A having 25 patients with severe preeclampsia (diastolic blood pressure $\geq 110 \mathrm{mmHg}$, albuminuria $\geq 2+$ ) and group $1 \mathrm{~B}$ having 25 patients with mild preeclampsia (diastolic blood pressure $\leq 110 \mathrm{mmHg}$, albuminuria of traces to +1 ), Group 2 was control group comprising 50 age, parity and gestation matched, normotensive pregnant women. Haemoglobin, urine, blood urea, serum uric acid and creatinine were estimated. Oral glucose tolerance was carried according to criteria laid down by O'Sullivan and Mahan ${ }^{6}$ by giving $100 \mathrm{~g}$ glucose dissolved in water and blood samples were collected fasting and at 60,120 and 180 minutes. Blood 
glucose was estimated by glucose oxidase peroxidase method.'

\section{RESULTS}

The levels of blood urea and serum uric acid were significantly higher in severe preeclampsia as compared to mild preeclampsia $(\mathrm{p}<0.01$ in both the parameters).

The mean fasting, one hour and two hour blood sugar levels in severe preeclampsia were significantly lower as compared to control $(\mathrm{p}<0.05)$ as well as mild preeclampsia ( $p<0.05)$. There was no statistically significant increase in fasting and one hour blood sugar in mild preeclampsia as compared to control. 2nd and 3 rd hour values were almost equal in mild preeclampsia and control (Figure 1).

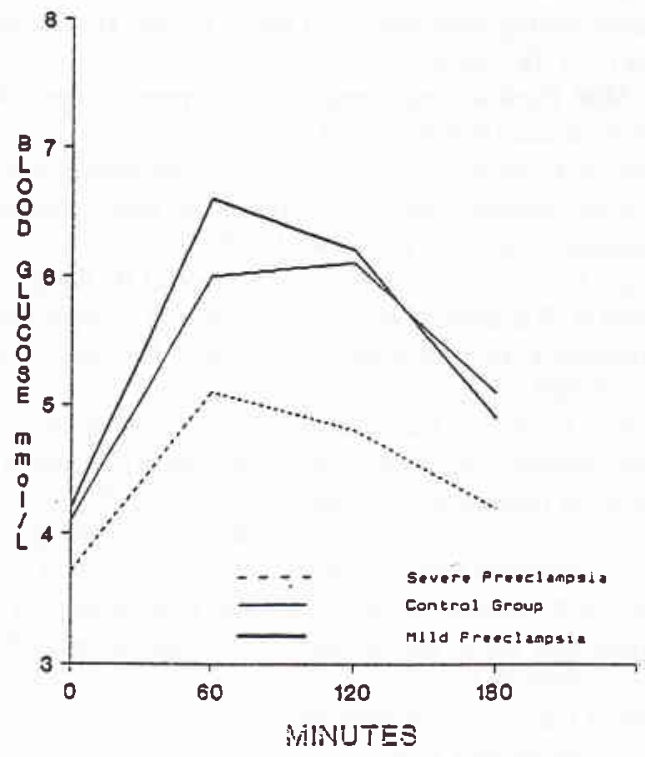

Figure 1. Blood glucose curve in study and control group

Incidence of hyperglycaemia in mild preeclampsia was $24 \%$ and in severe preeclampsia was $6 \%$ whereas incidence of hypoglycaemia in mild preeclampsia was $4 \%$ and severe preeclampsia was $8 \%$. There were 15 preterm and 10 term deliveries in severe preeclampsia. While in mild preeclampsia and control group majority of patients delivered at term and only 6 patients each had preterm delivery. (Table 1) Mean birth weight of term babies of hyperglycaemic patients was significantly higher as compared to normoglycaemic and hypoglycaemic patients in study group ( $p<0.001$, Table 2). Five babies were large for date in mild preeclampsia as compared to four in control and none in severe preeclampsia.
Table 1. Neonatal complications in study and control group

\begin{tabular}{llll}
\hline \multirow{2}{*}{ Complications } & \multicolumn{3}{c}{ No. of cases } \\
\cline { 2 - 4 } & Group 1A & Group 1B & Group 2 \\
\hline $\begin{array}{l}\text { Preterm } \\
\text { (Mean birth weight, g) }\end{array}$ & $15(1600)$ & $6(1800)$ & $6(1900)$ \\
Term & & & \\
(Mean birth weight, g) & $10(2400)$ & $19(2800)$ & $44(3200)$ \\
Birth asphyxia & 11 & 4 & 4 \\
Hyperbilirubinemia & 9 & 6 & 5 \\
Hypoxia & 1 & 4 & 0 \\
Congenital malformation & 0 & 0 & 2 \\
Perinatal mortality: & & & $1(2 \%)$ \\
$\quad$ Still birth & First week death & $3(16 \%)$ & $1(4 \%)$ \\
\hline
\end{tabular}

Table 2. Effect of abnormal glucose tolerance on mean birth weight in various groups $(\mathrm{g}$, mean $\pm S D)$

\begin{tabular}{lrlll}
\hline Groups & Number & $\begin{array}{l}\text { Birth weight } \\
\text { in hypergly- } \\
\text { caemics }\end{array}$ & $\begin{array}{l}\text { Birth weight } \\
\text { in hypogly- } \\
\text { caemics }\end{array}$ & $\begin{array}{l}\text { Birth weight } \\
\text { in normogly- } \\
\text { caemia }\end{array}$ \\
\hline $\begin{array}{l}\text { 1. Preterm } \\
\text { Term }\end{array}$ & 15 & $2200 \pm 0.3$ & $1500 \pm 0.4$ & $1600 \pm 0.5$ \\
2. Preterm & 6 & $3500 \pm 0.7$ & $2500 \pm 0.4$ & $2500 \pm 0.3$ \\
Term & 44 & $3400 \pm 0.6$ & $2600 \pm 0.8$ & $3000 \pm 0.4$ \\
\hline
\end{tabular}

Group 1 Hyperglycaemics Vs. Normoglycaemics $\mathrm{p}$ value $<0.001$

Group 1 vs 2 (Normoglycaemics) - p value $<0.001$

\section{DISCUSSION}

In present study $78 \%$ of preeclamptic women had edema feet as compared to $22 \%$ in normotensive control. Thomson ${ }^{8}$ reported edema in $85 \%$ of preeclamptic and $40 \%$ normotensive pregnant. Serum uric acid was significantly higher in severe preeclampsia $(0.034 \pm$ $0.6 \mathrm{mmol} / \mathrm{l})$ as compared to mild preeclampsia $(0.027$ $\pm 6 \mathrm{mmol} / \mathrm{l})$, $(\mathrm{p}<0.01)$. Mean fasting blood glucose in severe preeclampsia $(3.7 \pm 0.5 \mathrm{mmol} / \mathrm{l})$ was significantly lower as compared to mild preeclampsia (4.2 $\pm 0.8 \mathrm{mmol} / \mathrm{l}),(\mathrm{p}<0.5)$.

Our findings are comparable to those of $\mathrm{Singh}^{9}$ and Yamamoto $^{10}$; where mean values were $3.3,3.6 \mathrm{mmol} / 1$ respectively. All the postprandial values in severe preeclampsia were significantly lower as compared to control ( $p<0.001)$. Whereas in mild preeclampsia, first hour post prandial value was higher than control and second hour values were similar in mild 
preeclampsia and control. Similar observations were made by Tallarigo. ${ }^{11}$

Incidence of hyperglycaemia and hypoglycaemia was significantly higher in the study groups. In severe preeclampsia $44 \%$ had hypoglycaemia and $56 \%$ had normoglycaemia. Whereas Long ${ }^{12}$ found hypoglycaemia in $22.3 \%$ of cases and hyperglycaemia and $4 \%$ had hypoglycaemia and rest were normoglycaemic. These findings are consistent with those of Yamamoto. ${ }^{10}$ Incidence of gestational diabetes in study and control groups was $6 \%$ and $4 \%$ respectively. Singh $^{3}$ reported $26.7 \%$ incidence of gestational diabetes which he attributed to anoxia of $\beta$-cells in preeclampsia. According to Long ${ }^{12}$ abnormal glucose tolerance is more likely to precede the onset of preeclampsia than to be a consequence of it. Reduced maternal supply of nutrients to the fetus may be the cause of preeclampsia as fetal growth retardation often precedes the appearance of the signs of preeclampsia.

In severe preeclampsia with hypoglycaemia incidence of prematurity was significantly higher $(60 \%)$ more often in hypoglycaemics. Mean birth weight of term babies of severe preeclampsia was significantly lower than mild preeclampsia and control. It was also found that mean birth weight in hyperglycaemics was significantly higher than normoglycaemics both in study and control groups. No large for date baby was seen in hypoglycaemics while 5 patients with mild preeclampsia and four normotensive control had large for date babies. Various studies have similar results. ${ }^{11,14-17}$

Hypoglycaemia was more common in severe preeclampsia while hyperglycaemia was seen in mild preeclampsia. Fetal morbidity and mortality was significantly increased in preeclamptic women with abnormal blood glucose levels and hypoglycaemia had omnious significance with regards to perinatal death. Blood glucose analysis may serve to predict fetal outcome in cases of preeclampsia.

\section{REFERENCES}

1. Lind T. Metabolic changes in pregnancy relevant to diabetes mellitus. Post Grad Med J 1979;55:353-60.

2. Spellacy WN, Goetz FC. Plasma insulin in normal late pregnancy. New Engl J Med 1963;268:988-97.

3. Baumann G, Puavilai G, Freinkel N, Domout LA, Metzger BE, Levene HB. Hepatic insulin and glucagon receptors in pregnancy, their role in enhanced catabolism during fasting. Endocrinol 1981;108:1979.

4. Freinkel N. Banting Lecture 1980 of pregnancy and progeny. Diabetes 1980;29:1023.

5. Burt RL. Peripheral utilization of glucose in pregnancy and preeclampsia. Obstet Gynecol 1955;6:51-4.

6. O'Sullivan JB, Mahan CM, Charles D, Dandroo RV. Medical Treatment of gestational diabetes. Obstet Gynecol 1974;43:817-21.

7. Maclanchar DM. Glucose, other sugars and ketones. In: Gowenlock AN ed. Practical clinical Biochemistry. 6th ed. Great Britain; Heineman professional publishing 1988;3202.

8. Thomson AM, Hytten RE, Billewicz WZ. The epidemiology of edema during pregnancy. J Obstet Gynec $\mathrm{Br}$ Common wealth 1971;78:520-9.

9. Singh MM. Carbohydrate metabolism in preeclampsia. Br J Obstet Gynecol 1976;83:124-31.

10. Yamamoto K. Studies of plasma insulin in women and effect of glucose administration in toxemia of late pregnancy. Tokushima J Exp Med 1967;14:91-106.

11. Tallarigo L, Giampetro O, Penno G, Miceoli R, Gregori G, Navalesi R. Relation of glucose tolerance in complications of pregnancy in non-diabetic women. $\mathrm{N}$ Engl $\mathrm{J}$ Med 1986;315:989-92.

12. Long PA, Abell DA, Beischer NA. Importance of abnormal glucose tolerance (hypoglycaemia and hyperglycaemia) in aetiology of preeclampsia. Lancet 1977;1:923-5.

13. Singh M, Giri SK, Ramachandran K. Intrauterine growth curves in live bom babies. Indian Paediatr 1974;11:475-80.

14. Lindsay MK, Graves W, Klein L. The relationship of one abnormal test value and pregnancy complications. Obstet Gynecol 1989;73:103-6.

15. Campbell DM. Glucose tolerance in complicated pregnancies. In: Sutherland HW, Stowers JM eds. Carbohydrate metabolism in pregnancy and newborn. New York: Springer-Verlag Berlin Heidelberg 1979;509-14.

16. Long PA, Abell DA, Beischer NA. Fetal growth retardation and preeclampsia. Br J Obstet Gynecol 1980;87:13-16.

17. Kapoor M, Aggarwal N, Jain PK, Sethi RS, Gupta U, Latika G. Perinatal outcome in hypertensive disorders of pregnancy. J Obstet Gynecol India 1991;41:162-5. 